\title{
クラシファイアシステムを用いた競争環境下における 電力小売事業者群のエージェントベースシミュレーション*
}

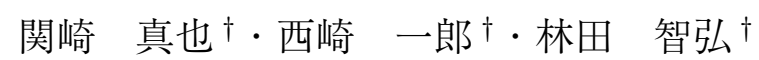

\author{
Agent-based Simulation of Retailers under Competitive \\ Environment using Classifier System*
}

\author{
Shinya SEKIZAKI ${ }^{\dagger}$, Ichiro NISHIZAKI ${ }^{\dagger}$ and Tomohiro HAYASHIDA ${ }^{\dagger}$
}

\begin{abstract}
This paper presents a novel simulation system to analyze adaptive behaviors of agents in a deregulated electricity retail market. We develop a learning framework which enables the agents to autonomously acquire the action rules. In this paper, the XCS (extended classifier system) is employed as a learning algorithm of the agents. XCS can efficiently generate action rules in the dynamic environment such as the deregulated retail market affected by the interaction among many agents. The artificial retail market shows complicated behavior by the interaction among the agents, and therefore the agent-based simulation can provide some technical findings due to the interactions among autonomous agents which are not always rational in a sense of optimal behaviors. We provide new insights based on the behavior analysis of the agents in the artificial retail market simulation.
\end{abstract}

\section{1.はじめに}

2016 年 4 月 1 日から，わが国では小売の全面自由化が 開始されており, すべての需要家が電力供給を受ける小 売事業者を任意に選択することが可能になる。今後経過 措置期間を経た後に競争の進展状況などを考慮して規制 料金が廃止される予定であり，その後は自由競争のもと で電力システムの効率化が図られることになる。経済学 における一般論として, 競争が十分に活性化された市場 では，取引される財に関する不当な料金設定が駆逐され ることで市場が効率化することが期待される，一方，自 由化が開始されている海外の一部では電気料金上昇など の問題が発生しているため $[1,2]$, これら諸問題の要因を 市場分析により明らかにすることが重要である.

市場分析手法には統計的な分析の他に均衡分析，およ びマルチエージェント分析が知られている [3]. 均衡分析 は，合理性をもつ経済主体の行動を記述可能な数理モデ ルを定式化し, 均衡条件を満たす解を導出して経済主体 の行動分析を行う手法である。発電事業者や小売事業者 の入札に関する先行研究ではこの均衡分析は広く採用さ

* 原稿受付 2016 年 12 月 12 日

* 広島大学 大学院 工学研究科 Graduate School of Engineering, Hiroshima University; Kagamiyama, HigashiHiroshima city, Hiroshima 739-8527, JAPAN

Key Words: electricity deregulation, multi-agent based simulation, adaptive behavior analysis, classifier system.
れている $[4,5]$ が，小売取引に関しては意思決定問題を 主眼に置いた先行研究がほとんどを占めており, 電力調 達量や電気料金の最適化問題を数理モデルとして定式化 し, 小売事業者の行動をモデル化している [6-23]. 小売 事業者間の均衡分析に関する先行研究が少ないのは, 小 売事業者と需要家間の契約締結は 0-1のバイナリ変数で 表現されるため, 均衡条件の制約式が微分不可能になる など，均衡条件の定式化が困難であるためであると考え られる。

上記の先行研究では小売事業者の合理性を仮定して おり, 必ずしも合理的に行動するとは限らない現実の経 済主体の行動を忠実に模擬可能であるとは限らない。ま た, 過去の経験に基づいて適切な行動を学習していく小 売事業者の適応的な行動や, 競争環境下における複数の 小売事業者間の相互作用に起因する諸現象の説明には 不向きである [24]. 一方で, 適応的行動分析にエージェ ントベースシミュレーションは適している [25]. 数理モ デルベースの均衡分析とエージェントベースシミュレー ションは相補的な関係にあり $[25]$, 一側面からの知見や 結論に限定されることなく, 複数の分析から得られた知 見を包括した結論を導くためにも，エージェントベース シミュレーションは重要である。しかし，電力市場にお けるエージェントベース分析に関する先行研究では学習 の難しさから小売取引を模擬した検討が十分になされて いない $[26,27]$ ため，本論文では競争環境下における小 
売事業者群のエージェントベースシミュレーションを実 施する.

電力市場におけるエージェントの学習には強化学習を 用いたものが多い [3,25-34]が，Q 学習などの一般的な 強化学習手法では, 競争環境下における複数の小売事業 者の学習が困難になる. Matrix gameによるエージェン トベースシミュレーション [3]のように限定的な環境，あ るいはプレイヤー数が少ない環境を仮定すれば一般的な 強化学習手法でも学習可能であると考えられるが, 不確 実に変動する市場価格や需要など小売事業者が認識する 環境は複雑であり，また複数の小売事業者間の競争によ り報酬が変動する状況では，学習が著しく非効率になる. そこで，本論文ではクラシファイアシステムの一種であ るXCS(extended classifier system)[35] を用い, 小売事 業者エージェント群が自律的に学習可能なシステムを構 築する。条件部にdon't care (\#) をもつクラシファイア システムは一般化の機能が簡便に実装されており，複数 の状況に適合するクラシファイアにより, 効率的な学習 を可能にしている [36]. また，予測報酬べースの学習機 構を有するXCS は，本論文で扱う不確実かつ競争環境 のように報酬が不確実に変動するような環境においても， 効率的に学習を行うことが可能である。

本論文の構成は下記の通りである，2.では，小売市場 における先行研究のサーベイ結果に基づいて本論文の位 置づけについて述べ， 3. でXCSについて簡単に説明す る. 4.では，想定する小売市場モデルについて述べる． 5. では小売事業者のモデルを，6. では需要家のモデル について述べる。 7.では, 構築したマルチエージェント システムを用いた数值シミュレーションを実施し, 得ら れた結果について考察する．最後に，8.で本論文を概説 する。

\section{2. 本論文の位置づけ}

小売取引における経済主体である小売事業者, 配電 系統運用者 (DisCo: distribution company), 卸売業者, LSE(load service entity) に関する先行研究のサーベイ 結果を Fig. 1 に要約する.

\section{1 数理モデルを用いた先行研究}

先行研究の [6-8,18,20-22] では，先渡取引を用いた小 売事業者のリスクヘッジを考慮した意思決定問題を取り 扱っている. [9] では小売事業者の電気料金決定問題を数 理モデルを用いて定式化しており，CVaR (conditional value at risk) 最大化問題を解くことで最適な電気料金 を決定している. [10]では電気料金に対する需要家の応 答を考慮したうえで小売事業者の電力調達量と電気料金 決定問題を数理モデルを用いて定式化している。また， DisCo R Retailer として扱い，市場からの電力調達量の 最適化や, 電気料金決定, 自家発の発電量最適化に関す る研究も存在する [11-16]. [17,19,23]についても同様に,

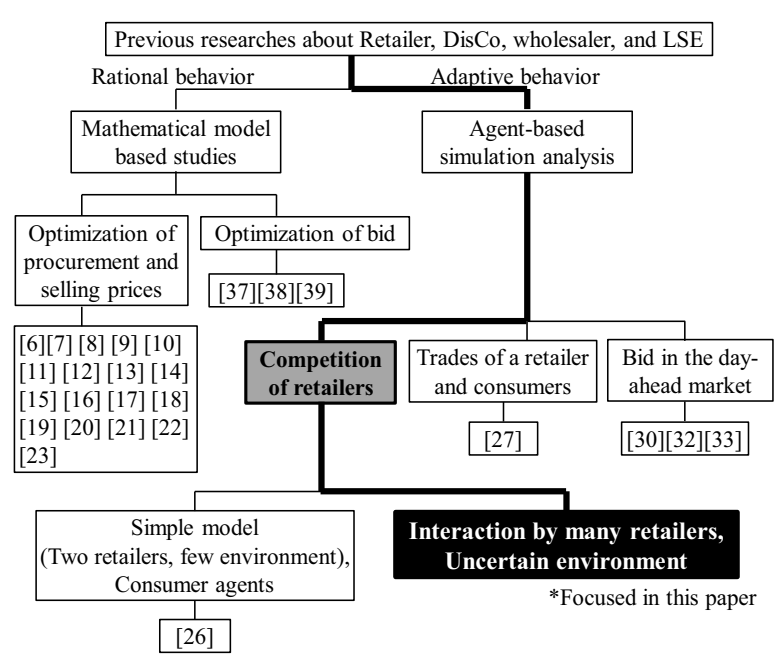

Fig. 1 Previous researches and focus of this paper

市場価格や需要といった不確実な要素を考慮した意思決 定問題を対象としている. 小売事業者や需要家による前 日市場での入札を対象とした研究も一部存在する [37-39] が，小売事業者に関する先行研究としては市場そのもの の分析よりも意思決定問題に焦点があてられているもの が多く, 電気料金に関する小売事業者間の均衡分析を取 り扱った先行研究は著者らの知る限り存在しない.

入札を扱っている [37-39] を除き, 上記の先行研究の ほとんどすべてにおいて，前日市場における経済主体は price-taker として扱われており，電気料金決定にあたっ ては入札行動を考慮しないモデル化が一般に広く採用さ れている。

\section{2 エージェントベースの先行研究}

電力市場におけるエージェントベースシミュレーショ ン [3,25-34] のうち, 小売事業者をエージェントとし て扱った先行研究は, 著者らの知る限り Abrate et al. (2006)[26] と Yousefi et al. (2011)[27] のみである. 先 行研究が少ない理由はいくつか考えられるが, 理由の一 つはエージェントの学習が困難であることである. 小売 事業者と需要家間の契約は, 基本的には「契約する」か 「契約しない」の二通りしかないため, 競争環境下では 契約する需要家数が離散的かつ流動的に変動し, 報酬が 安定しない. また, 市場価格や需要は不確実に変動する ため, これも報酬変動の要因となる。そのため, Q 学習 といった一般的な強化学習では学習が困難である.

Yousefi et al. (2011) では, 需要家の価格弾力性を考 慮したうえで, 小売事業者エージェントによるリアルタ イムプライシングを扱っているが，小売事業者間の競争 が明示的に考慮されていない. Abrate et al. (2006)は 著者らの知る限り小売事業者間の競争分析が行われてい る唯一の論文であるが, 小売事業者エージェント数が 2 名の場合のみを扱っており, 小売事業者間の競争が十分 に検討されているとは言いがたい. 


\section{3 位置づけのまとめ}

すでに述べたように，先行研究では小売取引における 経済主体の意思決定問題を取り扱っていることがほとん どであり，電気料金に関する競争を行う小売事業者群の 行動分析については十分な検討がなされていない. また, エージェントベースシミュレーションにおいても, 競争 環境下における小売事業者群の行動分析が十分とはいえ ない $[26,27]$. 小売市場全体における本論文の位置づけ としては, 先行研究で明らかにされていない「電気料金 に関する競争環境下での小売事業者群の適応的行動分 析」となる。ここで言及している「競争環境」とは，電 気料金を決定する際に他の小売事業者がライバルとなる 状況を指す。したがって，前日市場において小売事業者 を price-taker として扱っている先行研究 [6-23] 踏襲 し，小売事業者を price-taker と仮定し，他の小売事業 者との競争に焦点をあてる．小売事業者が前日市場にお いて price-maker となる場合，小売事業者による入札行 動 $[37,38]$ や発電事業者による発電機起動停止計画や入 札，市場運用者による約定処理 [39] を考慮してモデル化 を行う必要があるが，これは本論文の範囲を超えるため， 取り扱わない．同様に, リスク態度を考慮した場合の行 動分析は本論文の範囲を逸脱するため, 電力調達は前日 市場からのみとし, 先渡取引や自家発は考慮しない.

\section{XCS}

ここでは，XCSの学習機構について簡単に説明する が，3.の内容は文献 [35]にしたがっており，詳細につい てはこちらを参照されたい。

\section{1 クラシファイァ}

XCS[35] は, クラシファイアとよばれるルール群をも つ.クラシファイアは（IF：条件, THEN：行動）の組 合せから成るルールで表現され，環境にマッチするか否 かの比較を行う条件部と, 環境にマッチした後にとる行 動を示す行動部から構成される。ここでいう “マッチ”と は，環境状態と条件部が一致することをいう。環境状態 は 0,1 のビット列で，条件部は 0,1 のビット列および don't care (\#)で形成され, don't care (\#)は任意の環 境状態にマッチ可能な汎用的な条件部を表現できる。 ク ラシファイアは条件部と行動部の他に予測報酬, 予測誤 差, 適合度, 重複数の評価值をもつ. 重複数は条件部と 行動部が等しいクラシファイアを集約した数を示す。こ こで，クラシファイアの集団を $[P],[P]$ に含まれる $i$ 番 目のクラシファイアを $c l_{i}$ と表し, $c l_{i}$ の条件部, 行動部, 予測報酬, 予測誤差, 適合度, 重複数をそれぞれ $c l_{i} . C$, $c l_{i} . A, c l_{i} . p, c l_{i} . \epsilon, c l_{i} . F, c l_{i} \cdot n$ とする.

\section{2 学習機構}

$\mathrm{XCS}$ は環境状態が与えられると，まず環境状態とマッ チするクラシファイアを探し，マッチセット $[M] \subseteq[P]$ を生成する。 $[M]$ 内に存在するクラシファイアがもつ行
動部の種類の数を $\theta_{[M]}$ とする. $\theta_{[M]}<\theta_{m n a}$ の場合, 条 件部が環境とマッチし, かつ $[M]$ 内に存在しない行動を もつクラシファイアを $\theta_{[M]}=\theta_{m n a}$ となるまで生成する. この操作は covering とよばれ, $[P]$ に存在しないがより 高い報酬を獲得可能な行動をもつクラシファイアを効率 的に探索することができる.

マッチセット $[M]$ を生成した後, $[M]$ に含まれるク ラシファイアがもつ行動を一つ選択する。具体的には, (1) 式を用いて各行動の予測報酬を計算して prediction array：PAを生成し，PAに格納された值に基づき行動 を選択する。

$$
P A\left(A_{j}\right)=\frac{\sum_{c l_{k} \in[M], c l_{k} \cdot A=A_{j}} c l_{k} \cdot p \times c l_{k} \cdot F}{\sum_{c l_{k} \in[M], c l_{k} \cdot A=A_{j}} c l_{k} \cdot F}
$$

(1) 式における $A_{j}$ は $j$ 番目の行動を表す.エージェン 卜の適応的な行動を模擬するために，行動選択の際には $\epsilon$-greedy を用い, 確率 $p_{\text {explr }} \leq 1.0$ でランダムに行動を 選択し，確率 $\left(1.0-p_{\text {explr }}\right)$ で PAに格納された值が最も 大きい行動を選択する．選択された行動を $A^{*}$ とすると， マッチセット $[M]$ に含まれるクラシファイアのうち, 行 動が $A^{*}$ と等しいクラシファイアから成るアクションセッ 卜 $[A] \subset[M]$ を生成する.

選択した行動 $A^{*}$ を実行後，得られた報酬 $r$ に基づい て $[A]$ 内のクラシファイアの評価值を更新する。これを $(2) \sim(6)$ 式に示す.

$$
\begin{aligned}
& c l_{i} . p \leftarrow c l_{i} \cdot p+\beta\left(P-c l_{i} \cdot p\right), \quad \forall c l_{i} \in[A] \\
& c l_{i} . \epsilon \leftarrow c l_{i} \cdot \epsilon+\beta\left(\left|P-c l_{i} \cdot p\right|-c l_{i} . \epsilon\right), \quad \forall c l_{i} \in[A] \\
& c l_{i} . F \leftarrow c l_{i} . F+\beta\left(\kappa_{i}^{\prime}-c l_{i} . F\right), \quad \forall c l_{i} \in[A] \\
& \kappa_{i}^{\prime}=\frac{\kappa_{i} \times c l_{i} \cdot n}{\sum_{c l_{k} \in[A]} \kappa_{k} \times c l_{i} . k}, \forall c l_{i} \in[A] \\
& \kappa_{i}=\left\{\begin{array}{l}
1.0, \quad \text { if } \epsilon<\epsilon_{0} \\
\alpha\left(\frac{\epsilon}{\epsilon_{0}}\right)^{-\nu}, \quad \text { otherwise }
\end{array}, \forall c l_{i} \in[A]\right.
\end{aligned}
$$

$(2) \sim(6)$ 式における $P$ は， $[A]$ に含まれるクラシファイ アの評価值を更新する際に用いる值であり，一般的には 報酬 $r$ と $P A$ 中の最大值 $\max P A$, および割引率を用い て計算される $[35] .4$.にて後述するが，本論文で扱うの はある期間におけるエージェントの利益を最大化する当 該期間の行動を決定する問題であるため, エージェント の意思決定はステップごとに独立している．そのため， クラシファイアシステムが扱う問題クラスは single-step 問題となり，本論文では割引率は 0, つまり, $P=r$ と している。現実には長期的な利益を最大化するために multi-step 問題として扱うことが自然な場合もあるが, 本論文では競争環境を模擬しているため報酬が動的に変 化しており，事前検討において割引率を用いた場合に学 習性能が著しく低下したため，本論文では対象としない． これについては今後の課題とする。 $\beta$ は学習率であり, 学習の更新速度を表すパラメータである. $\kappa_{i}$ と $\kappa_{i}^{\prime}$ はそ 


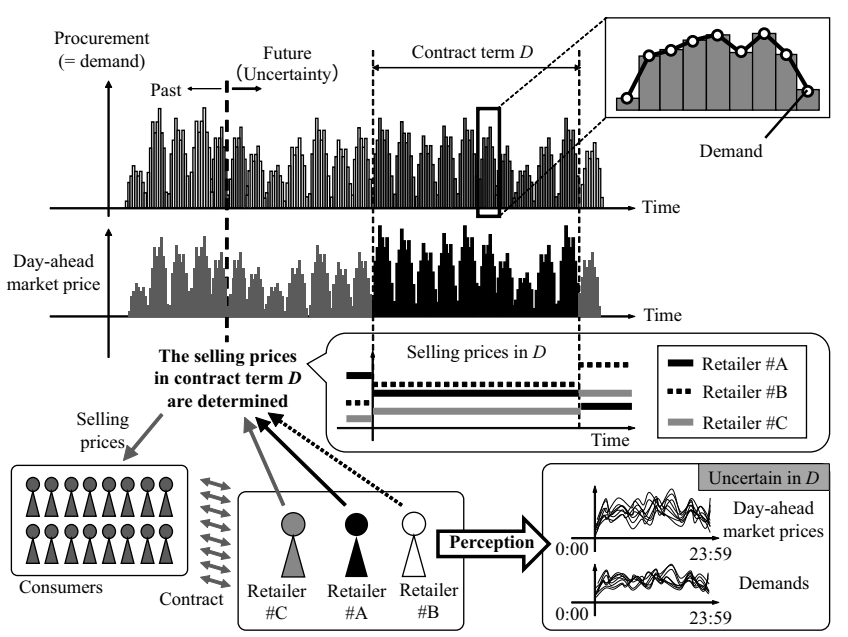

Fig. 2 Trade by retailers and consumers

れぞれクラシファイアの正確さおよび相対的な正確さを 表し， $\epsilon_{0}$ は許容誤差である。 $\alpha$ と $\nu$ は学習パラメータで ある。

パラメータ更新後, 遺伝的アルゴリズム (genetic algorithm: GA) を用いてより環境に適応したクラシファイ アを生成する，GAでは，クラシファイアの適応度 $c l_{i} . F$ の值を選択確率として二つのクラシファイアが親個体と して選択され，この親個体に対して交叉および突然変異 を実行し，子個体を生成する。生成した子個体はクラシ ファイアの集団 $[P]$ に追加される，新たに生成された個 体が $[P]$ に追加される際，すでに同じ個体が存在すれば その個体の重複度 $c l_{i} . n$ を 1 だけ増加させる. $[P]$ が最 大サイズを超えた場合, 適合度の低いクラシファイアを ルーレット選択により削除する。

\section{4. 競争モデル}

Price-taker である複数の小売事業者が需要家と契約す る状況での競争環境を模擬するために，本論文では [6-9] の意思決定モデルを参考に，Fig. 2 の市場モデルを想定 する。すでに述べたように，本論文の位置づけとしては 競争環境下に扮ける price-takerである小売事業者の適応 的行動分析であるため, 小売事業者の決定变数は電気料 金となる，現実の状況を反映し，前日市場価格や需要は 不確実に変動するものとする，小売事業者が需要家へ電 力供給を行う契約期間を $D$, 契約期間に含まれる電力受 渡日を $d \in D$ とし, 電力受渡日は 1 日が 30 分ごと 48 期 に分割される。茪事業者エージェント $i=1,2, \ldots,|N|$ の集合を $N$, 需要家 $j=1,2, \ldots,|L|$ の集合を $L ， 1$ 日の 期集合を $T=\{1,2, \ldots, 48\}$ とする，小売事業者は，将来 の契約期間 $D$ に扔ける市場価格と需要を意思決定の判 断に用いると考えることが自然である [6-23]ため，小売 事業者エージェント $i$ は， $D$ に打ける市場価格や需要に 対応する環境状態を知覚し, 需要家へ提示する $D$ におけ

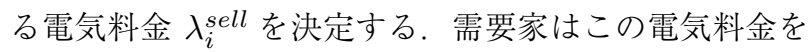
基に $D$ で契約する小売事業者を選択する。この取引を要

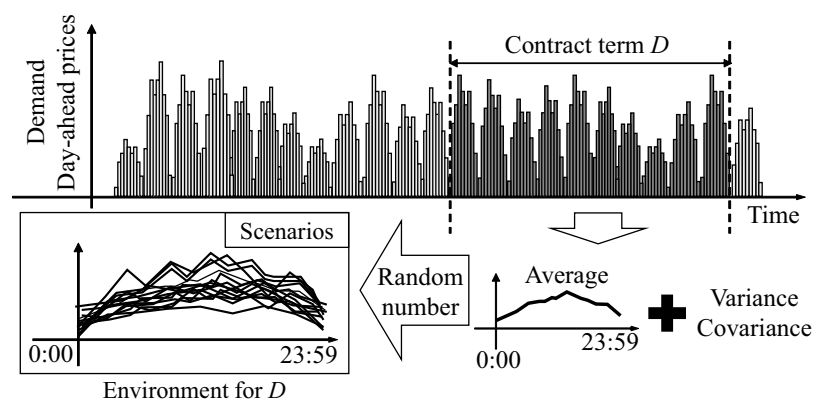

Fig. 3 Scenario generation

約すると，下記のようになる．

$<$ 取引概要 $>$

(1) 小売事業者エージェント $i=1,2, \ldots,|N|$ は, 契約 期間 $D$ に打ける電気料金 $\lambda_{i}^{\text {sell }}$ 決定する。茪 事業者エージェントは他のエージェントの行動を 知ることなく電気料金を決定する。

(2) 需要家 $j=1,2, \ldots,|L|$ は, 小売事業者エージェント $i=1,2, \ldots,|N|$ から提示される電気料金情報 $\lambda_{i}^{\text {sell }}$ に基づき, 電気料金が最も安価な小売事業者エー ジェント $i$ と契約する。ただし，スイッチングコ ストが存在する場合には電気料金とスイッチング コストの和が最小の小売事業者エージェントを選 択する。

(3) 需要家 $j$ と契約を締結する小売事業者エージェン 卜 $i$ は, 契約期間 $D$ に含まれる $d$ 日の $t$ 期に, 電力を前日市場価格 $\lambda_{d, t}^{D A}$ で調達し, 需要家 $j$ へ 電気料金 $\lambda_{i}^{\text {sell }}$ で販売する。

本モデルは現実の小売事業者の行動を忠実に再現して いるものではないが, 本論文では競争環境下に扔ける小 売事業者の適応的行動分析に主眼を置いており, 簡易的 ではあるが適応的に行動する複数の小売事業者エージェ ントによる競争を表現可能なモデルである。

\section{5. エージェントの学習}

\section{1 環境情報と条件部}

現実の前日市場価格㧍よび需要は不確実に変動し, 小売 事業者が電気料金を決定する段階では未知である [6-23]. これを模擬するため, 日本卸電力取引所 (Japan Electric Power eXchange: JEPX)[40]のスポット市場における 実績值（システムプライス）データおよび電気学会の地 域供給系統の「系統 III $66 \mathrm{kV}$ 架空線地中線混在系統（架 地混系統 $) 」[41]$ の需要データから, 契約期間 $D$ に扔け る前日市場価格および需要のシナリオ $[6-10,22]$ を生成 する。これを Fig. 3 に示す．シナリオは市場価格デー夕 と需要デー夕と等しい平均と分散をもつが, 一様乱数を 用いて生成されるため, 前日市場価格と需要は不確実に 変動する. シナリオ生成手法については付録に示す。

小売事業者は, 将来の契約期間 $D$ における前日市場価 格と需要を完全には予測することはできないが, 不確実 
性をもったシナリオ集合を意思決定の判断に用いる [22] と考えることが自然である。そこで，契約期間 $D$ ごとに 番号を割り振り，この番号を環境情報とすることで， シ ナリオ集合を知覚するものとする.

クラシファイアの条件部にはこの環境番号をビット列 に変換したものを格納する。条件部をビット列へ変換す る符号化の際には，隣接する符号間のハミング距離が 1 になるようにGray codeを用いる。契約期間 $D$ の市場 価格平均值が小さいものから順に $1,2,3, \ldots$ と環境番号 を割り振り, ビット列へ変換し, その後 Gray codeに変 換する.

\section{2 行動部}

環境情報が条件部とマッチした場合に，条件部に対応 した行動部により小売事業者エージェント $i$ は需要家に 提示する契約期間 $D$ の電気料金 $\lambda_{i}^{\text {sell }}$ を決定する。本論 文では 64 通りの電気料金を設定できるが，これは計算 負荷を考慮したためであると同時に，電気料金の刻み幅 が細かすぎる場合，報酬の差が小さくなり， クラシファ イアによる識別が適切に機能しないためである，市場価 格を下回る電気料金を設定するといった，経済主体の行 動として考えにくい行動を避けるため，契約期間 $D$ の 市場価格平均值を下回る電気料金は選択できないように する.

\section{3 報酬}

需要家 $j$ と契約している小売事業者エージェント $i$ の 契約期間 $D$ における利益は, 需要家 $j$ の $d$ 日 $(d \in D)$ の $t$ 期の消費電力量 $P_{j, d, t}$ を, 電気料金 $\lambda_{i}^{\text {sell }}$ で販売し た場合の収入から， $\lambda_{d, t}^{D A}$ で $P_{j, d, t}$ を前日市場から購入 した場合の支出を差し引き，これをすべての期 $t \in T$ お よび契約期間 $d \in D$ について和をとった $r_{i, j}$ になる。こ れを契約しているすべての需要家について和をとったも のが契約期間 $D$ における小売事業者エージェント $i$ の 得る利益 $R_{i, D}$ である。 これを $(7) \sim(10)$ 式に示す.

$$
\begin{aligned}
& R_{i, D}=\sum_{j \in L} r_{i, j}, \quad \forall i \in N \\
& r_{i, j}=S_{i, j, D} \sum_{d \in D} \sum_{t \in T}\left\{\left(\lambda_{i, j}^{\text {sell }}-\lambda_{d, t}^{D A}\right) P_{j}^{c a p} P_{j, d, t}\right\}, \\
& \forall i \in N, \quad \forall j \in L \\
& S_{i, j, D} \in\{0,1\}, \quad \forall i \in N, \quad \forall j \in L \\
& P_{j}^{c a p} \in(0.0,1.0]
\end{aligned}
$$

(8), (9) 式における $S_{i, j, D}$ は小売事業者エージェント $i$ が需要家 $j$ と契約期間 $D$ において契約する場合に 1 , 契約しない場合に 0 となるバイナリ変数である。 $P_{j}^{c a p}$ は 需要家の負荷容量を示す係数であり, 需要家ごとの負荷 容量の違いを模擬するために使用する。

\subsection{XCS による学習機構}

小売事業者エージェントの報酬は, 他の小売事業者 エージェントが設定する電気料金によって変動する。ま

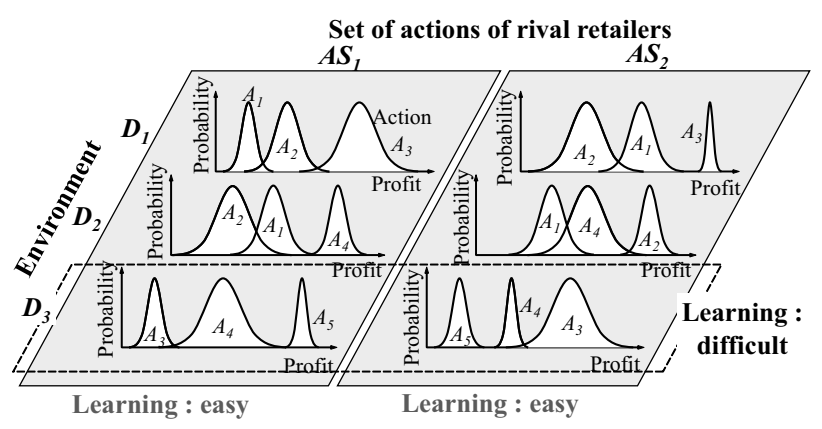

Fig. 4 Learning difficulty by variation of rewards; Column: easy, Row: difficult

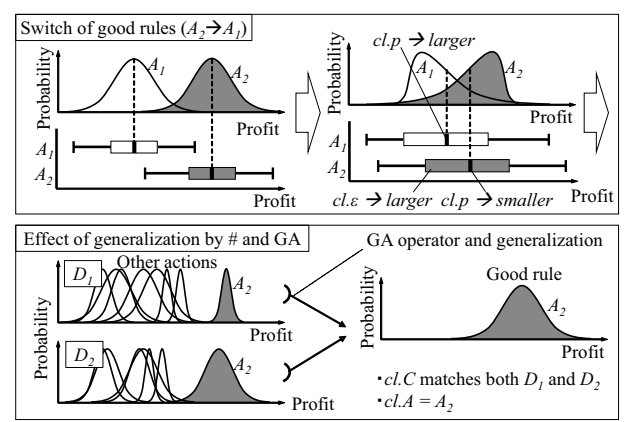

Fig. 5 Autonomous learning by XCS

た市場価格や需要も不確実に変動するため, 小売事業 者エージェントが得る報酬は確率的に分布する。報酬が 確率的に分布する様子を図示したものを Fig. 4 に示す. Fig. 4 は, 行が環境 $D$, 列が競争相手の小売事業者エー ジェント群の行動集合 $A S$ に対応している。競争相手の 小売事業者エージェント群の行動が一定（=列に対応） であれば学習は容易であるが, $A S$ が変動する場合（= 行に対応），環境 $D$ が固定であったとしても報酬の分布 が場合によっては大きく変動してしまう，報酬の分布が 動的に大きく変動する場合，適切なルールを獲得するこ とが難しいが, 予測報酬ベースの学習機構と don't care (\#)をもつXCS は Fig. 4 の状態に対応できる.

Fig. 5 の上段は, 報酬の変動に応じて適切なルールが 交代する様子を示したものである，XCSでは予測報酬 が大きく，かつ予測精度が高い行動が選択されるため， Fig. 5 上段左側では行動 $A_{2}$ が適切なルールとして獲得 されている. 競争相手の行動が変化し, 行動 $A_{2}$ を選択 した際の報酬が急減した場合, 予測報酬と適合度の両者 が低下するため，PAの值が急減し，Fig. 5 上段右側のよ うに行動 $A_{1}$ にルールが交代する。 また，競争環境下で は，安定的に競争相手に勝てるようなルールを獲得する ことが望ましいが，XCSは一般化およびGAによって 利益を安定的に獲得可能なルールを効率的に学習するこ とが可能である。 Fig. 5 の下段では，異なる環境 $D_{1}, D_{2}$ でも報酬が高い行動 $A_{2}$ を GA および don't care (\#)に より一般化して学習する様子を示したものである. 


\section{6. 需要家モデル}

現実の需要家の行動としては，契約を変更すること による金銭的，時間的，人的コスト等により，電気料金 が多少高価であっても契約相手を変更しない場合があ る $[1,2]$. 本論文では，契約する小売事業者エージェント を変更する際のスイッチングコストを考慮する，具体的 には，需要家 $j$ のスイッチングコストを表すスイッチン グコスト係数 $\rho_{j}^{S C}$ を設定し, $D$ における最も安価な電気 料金 $\lambda_{D}^{\min }$ が, $D-1$ に契約した小売事業者エージェント が $D$ に提示する電気料金を $\rho_{j}^{S C}$ 以上下回る場合に, $D$ における最も安価な電気料金を提示する小売事業者エー ジェント ret ${ }_{D}^{\min }$ と契約する。 それ以外の場合は， $D-1$ に契約した小売事業者エージェントとの契約を継続する. これを数式で表現すると，(11)〜 (15) 式のようになる.

$$
\begin{aligned}
& \lambda_{D}^{\min }=\underset{i \in N}{\arg \min } \lambda_{i}^{\text {sell }} \\
& \operatorname{Ret}_{D}^{\min }=\left\{i \mid \lambda_{i}^{\text {sell }}=\lambda_{D}^{\min }\right\} \\
& \operatorname{ret}_{D}^{\text {min }}=\left\lceil\text { rand } \times\left|\operatorname{Ret}_{D}^{\text {min }}\right|\right\rceil \\
& \text { Cont }_{j, D-1}=i \mid\left(S_{i, j, D-1}=1\right) \quad \forall j \in L \\
& \text { Cont }_{j, D} \\
& = \begin{cases}\operatorname{ret}_{D}^{\text {min }}, & \text { if } \lambda_{\text {Cont }_{j, D-1}}^{\text {sell }}-\rho_{j}^{S C} \leq \lambda_{D}^{\text {min }} \\
\text { Cont }_{j, D-1}, & \text { otherwise }\end{cases}
\end{aligned}
$$$$
\forall j \in L
$$

(12) 式の $\operatorname{Ret}_{D}^{\min }$ は契約期間 $D$ において最も安価な 電気料金を提示する小売事業者エージェントの集合であ り, $\left|R e t_{D}^{\min }\right|>1$ の場合, (13) 式を用いてランダムに小 売事業者を選択する. rand は $(0,1]$ の一様乱数である. (13) 式における「·〕は天井関数である. (14), (15) 式に おける Cont $_{j, D}$ は契約期間 $D$ において需要家 $j$ が契約 する小売事業者エージェント番号である.

\section{7. 数值シミュレーション}

\section{1 シミュレーションの流れ}

シミュレーションは, 小売事業者エージェントと需要 家の取引を時系列で実施していき，これを $N_{\text {max }}$ だけ繰 り返す。契約期間 $D$ は簡単化のため 1 ケとする.

\section{2 シミュレーション条件}

\subsection{1 市場価格}

市場価格データとして，日本卸電力取引所 (Japan Electric Power eXchange: JEPX)[40]のスポット市場 における実績值（システムプライス）の 2012 年 1 月 1 日 から 2015 年 12 月 31 日までの 1,461 日分の各期の值（総 デー夕数： $1,461 \times 48=70,128 ）$ を用いる．これをFig. 6 に示す．システムプライスデータは 4 年分存在するが, 学習を十分に行うためには 4 年では不足であるため， シ ステムプライスデータを繰り返し使用するが，5.1で述 ベたように市場価格シナリオを乱数を用いて生成するた め, 環境は動的に変動する

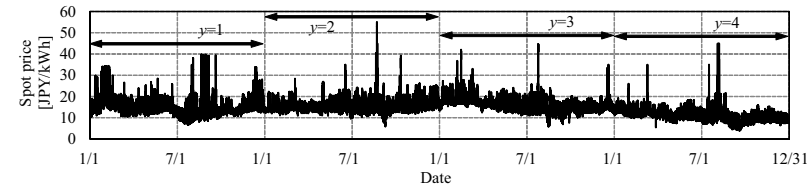

Fig. 6 Day-ahead market price data $\lambda_{d, t}^{D A *}$ in Appendix)
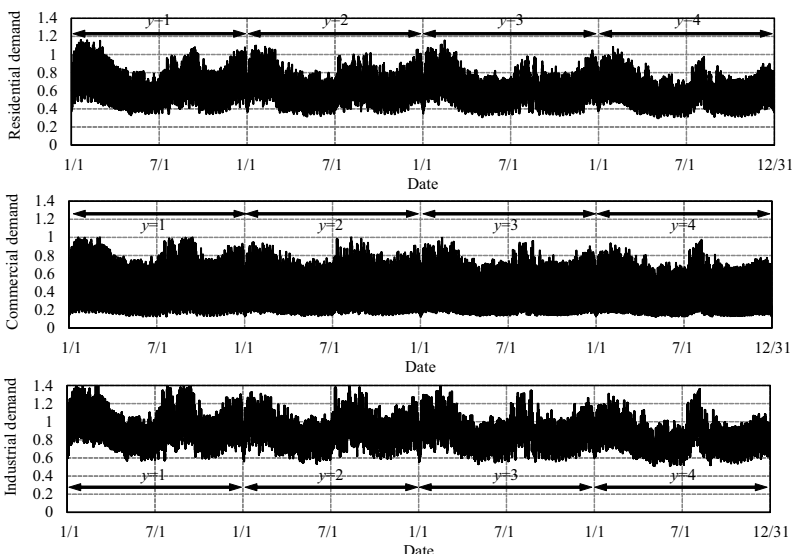

Fig. 7 Demand data; Upper: Residential, Middle: Commercial, Lower: Industrial

\subsection{2 需要}

電気学会の地域供給系統の「系統 III $66 \mathrm{kV}$ 架空線地 中線混在系統 (架地混系統)」[41]の需要デー夕を基に電 力需要 $P_{j, d, t}$ を生成する. 夏季を $6,7,8$ 月，冬季を 12 , $1 ， 2$ 月，春季を $3 ， 4 ， 5$ 月，秋季を $9 ， 10 ， 11$ 月として 定義し，1時間ごとのロードカーブを線形補完により 30 分ごとの需要（48期）に変換して用いる．毎日変動する 需要を模擬するため, スポット市場価格データに対応し た 2012 年 1 月 1 日から 2015 年 12 月 31 日までの東京 電力管内の需要実績デー夕 [42] を用い, 住宅, 商業, 工 業需要家の各季節，各期のロードカーブを平日，休日別 に作成する，需要デー夕は無次元である。作成した需要 データ $P_{j, d, t}$ を Fig. 7 に示す. 市場価格と同様に，需要 についても 4 年分のデータを繰り返し使用するが， $\mathbf{5 . 1}$ で述べたように需要シナリオを乱数を用いて生成するた め，環境は動的に変動する，需要生成手法の詳細につい ては付録に示す。

上記のように，データを 4 年分使用するため， 1 年の 市場価格と需要デー夕の組合せ（1月，2月，… 12 月 の一連のデータ）が 4 セット存在する．市場価格や需要 の周期的な特性を考慮し， 1 年分のデータセットについ ては 1 月から 12 月までに順に使用する。不確実性を模擬 するために，どの年が選ばれるかは一様乱数を用いてラ ンダムに選択される。つまり，シミュレーションは，(1 年目データ） 1 月， 2 月， $\cdots, 12$ 月， $\rightarrow(4$ 年目デー夕 $)$ 1 月， 2 月， $\cdots, 12$ 月，のように 1 年周期でランダムに 選択された年データを用いて生成された環境を用いて実 行する. 
Table 1 Learning parameters

\begin{tabular}{l|l}
\hline Maximum classifier size $N_{C L}$ & 4096 \\
\hline Condition part & 6 bit \\
\hline Available actions & 64 \\
\hline Learning rate & $\beta=0.2$ \\
Fitness function coefficient & $\alpha=0.1, \nu=5$ \\
GA parameter & $\theta_{G A}=48$ \\
Probability of crossover & $\chi=0.5$ \\
Probability of mutation & $\mu=0.01$ \\
Deletion parameter and $\delta$ & $\theta_{\delta}=20, \delta=0.1$ \\
Subsumption parameters & $\theta_{\text {sub }}=100$ \\
Probability for don't care & $p_{\#}=0.33$ \\
\hline$\epsilon$-greedy probability & $p_{\text {explr }}=\{1.0,0.01,0.00\}$ \\
\hline Minimum action size & $\theta_{m n a}=64$ \\
\hline
\end{tabular}

\subsection{3 需要家のスイッチングコストおよび負荷容量}

需要家ごとにスイッチングコスト係数 $\rho_{j}^{S C}$ を乱数 rand を用いて生成する。需要家のスイッチングコストを精度 よく定量的に調査，分析したデータが見つからなかった ため, 本論文では需要家のスイッチングコストの分布を 一様分布と仮定し, $(0,1]$ の一様乱数を用いてスイッチン グコスト係数 $\rho_{j}^{S C}$ を生成する. シミュレーションでは, $\rho_{j}^{S C}$ の最大值 $\rho_{\max }^{S C}$ を変化させた感度分析を実施する. 同様に，需要家の負荷容量 $P_{j}^{c a p}$ も $(0,1]$ の一様乱数を用 いて生成する。本論文では計算負荷を考慮して 10,000 人 の需要家を想定する. $\rho_{j}^{S C}$ の計算式を $(16)$ 式に示す.

$$
\rho_{j}^{S C}=\operatorname{rand} \times \rho_{\max }^{S C}, \quad \forall j \in L
$$

\subsection{4 パラメータ}

事前検討において, 学習初期は $\epsilon$-greedy の選択確率 $p_{\text {explr }}$ を大きく設定することで小売事業者エージェント のもつクラシファイアの平均值適合度が急激に上昇し, 小売事業者エージェント数にかかわらず 5,000 期程度で適 合度の増加が鈍化したため, $p_{\text {explr }}=1.0$ で 5,000 期の学 習を実施した後, $p_{\text {explr }}=0.01$ に変更して 5,000 10,000 期の学習を行い, 10,000 期以降は $p_{\text {explr }}=0.0$ でシミュ レーションを実施する。本シミュレーションモデルは競 争環境を模擬しており, 小売事業者エージェント数が多 いとクラシファイアの平均適合度は常に変動し収束しな いため, 平均適合度をシミュレーション終了の判断には 使えない. 電気料金については 20,000 期程度でほぼ収束 するという事前検討結果が得られたため，余裕をもって 50,000 期をシミュレーションの期数とする。すなわち, $N_{\text {max }}=50,000$ となる. エージェントの学習に用いるパ ラメータを Table 1 に示す。 パラメータの詳細について は文献 $[35]$ を参照されたい. パラメータは学習が効率 よく行われるように試行錯誤的に決定している。GA ついては一点交叉, ルーレット選択, 線形スケーリング
を用いる，小売事業者エージェントは，事前検討におい て電気料金を市場価格より著しく高く設定するような行 動は見られなかったため（独占市場の場合を除く），電 気料金最大值を $25.0[\mathrm{JPY} / \mathrm{kWh}]$ とする. 電気料金最小 值については $10.0[\mathrm{JPY} / \mathrm{kWh}]$ としたため, 小売事業者 エージェントは, $(25-10) /(64-1)=0.238[\mathrm{JPY} / \mathrm{kWh}]$ 刻みで電気料金を設定できる. [35]では (6) 式の許容誤差 $\epsilon_{0}$ は, 最大報酬の $1 \%$ 程度となっているが, 本論文で扱 うシミュレーションではエージェントの報酬が動的に変 動するため, 許容誤差 $\epsilon_{0}$ についてはあらかじめ設定する ことができない，そこで，各環境におけるエージェント が得た報酬の標準偏差を許容誤差 $\epsilon_{0}$ とする.

\section{3 シミュレーションケース}

シミュレーションを行う条件一覧を Table 2 に示す. 2.3 にて述べたように，本論文では小売事業者間の競争 に焦点を当てているため, 競争に及ぼす影響が大きいと 考えられる小売事業者数 $|N|$ と，スイッチングコスト係 数 $\rho_{\text {max }}^{S C}$ を変化させてシミュレーションを実施する。 シ ミュレーションは, Case 1, 2, ., 7 で小売事業者を増 加させ, Case (I)-(VI) でスイッチングコストを増加させ る. また, Case (a), (b), (c) はそれぞれ需要家種別が住 宅，商業，工業の場合である.

\section{4 シミュレーション結果 \\ 7.4.1 電気料金}

電気料金については Table 2 に示したようにシミュ レーション期数 50,000 期 $\times 126$ 試行データが存在するた め, 紙面の都合上, Case (a), Case $(1)(2)(3)(4)(5)(6)$, Case(I)(II)(VI) における結果をここでは示す。市場価格 の一か月平均值の, 学習最後の 480 か月 $(49,521$ 期から 50,000 期）における平均值を Fig. 8 に黒の直線で示す. また, 学習最後の 480 か月における, 各環境での電気料 金の分布をFig. 8 に示す. Fig. 8 の分布は箱ひげ図で表 記しており，一印は分布の中央值，十印は外れ值である。 Fig. 8 に示したグラフ上から順に Case $(1),(2), \ldots,(6)$, 左から順に $(\mathrm{I}),(\mathrm{II}),(\mathrm{VI})$ となっており，各グラフの上に はどのケースに対応するかの番号が示されている. Fig. 8 から読み取れる結果として，以下の点が挙げられる。

(1) 小売事業者数が増加するにつれ, 電気料金は下が る傾向にある。

(2) スイッチングコストが増加するにつれ，電気料金 は上がる傾向にある。

Case (a)(1)(I)(II)(VI) に関しては, 小売事業者は 1 名 しかおらず，独占的に電気料金を決定できるため，電気 料金は市場価格にかかわらず最大值の $25[\mathrm{JPY} / \mathrm{kWh}]$ 付 近にある。これは自明な結果である。

Case $(\mathrm{a})(2)(\mathrm{I})(\mathrm{II})(\mathrm{VI})$ については, 小売事業者は 2 名 おり競争環境にあるにもかかわらず，2名の小売事業者 はほぼ同じ值に電気料金を設定している。これは，電気 料金を下げて多くの需要家と契約するよりも， 2 名の小 
Table 2 Simulation conditions

\begin{tabular}{|c|c|c|}
\hline- & Case & Simulation \\
\hline Consumer type & (b) Commercial & \multirow{4}{*}{$\begin{array}{c}126 \\
\text { simulations } \\
\times \\
50,000 \text { periods }\end{array}$} \\
\hline Retailers numbers $|N|$ & (1) $1,(2) 2,(3) 4,(4) 8,(5) 16,(6) 32,(7) 64$ & \\
\hline Consumer numbers $|L|$ & \multirow{2}{*}{$\begin{array}{c}10,000 \\
(\text { I) } 00(\text { II) } 20(\mathrm{II}) 40\end{array}$} & \\
\hline Switching cost coefficient $\rho_{\max }^{S C}$ & & \\
\hline
\end{tabular}
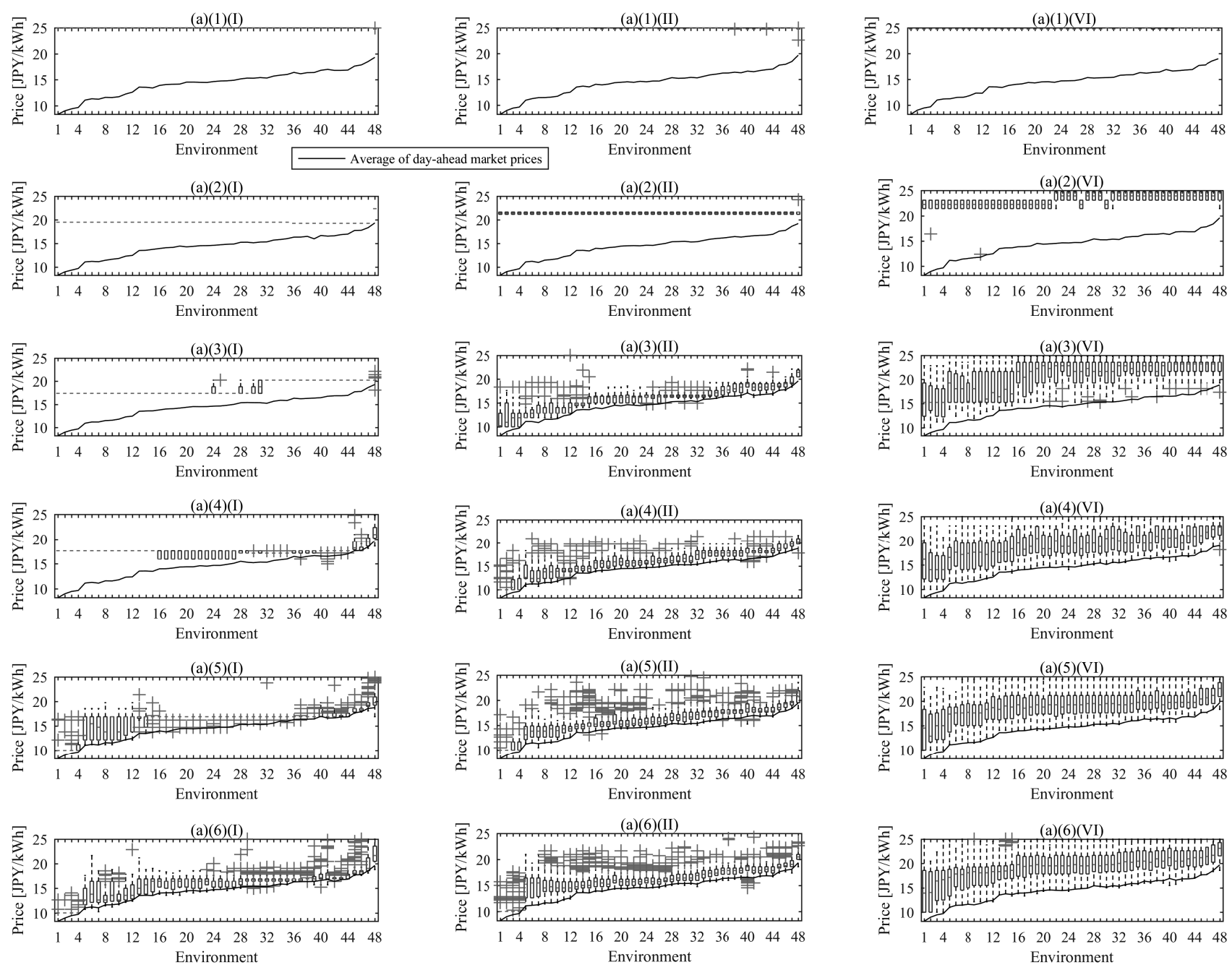

Fig. 8 The distribution of the selling prices from 49,521 to 50,000 periods

売事業者が同じ電気料金に設定する方が得られる利益が 大きいことを過去の経験から学習したためである。ただ し，電気料金を高くし過ぎると競争相手が值下げ行動を とり，顧客が競争相手に流れてしまうため，これを防ぐ ために電気料金は最大值を下回る值に設定されている.

小売事業者数が 4 名以上になる Case (a)(3)(4)の場合, 競争が激しくなるため, 市場価格付近まで電気料金を下 げる小売事業者が現れる。ただし，スイッチングコスト が大きいCase (a)(3)(VI), Case (a)(4)(VI) では, 電気 料金の分布はやや高めになっており，スイッチングコス トにより電気料金が上昇することを示している。一方 で，スイッチングコストが0である Case (a)(3)(I), Case (a) (4)(I) では, Case (2) と同様に複数の小売事業者がほ
ぼ等しい電気料金に設定する行動がみられる。これはス イッチングコストが 0 である場合, 最も安価な電気料金 を設定する小売事業者が独占的に需要家と契約するため, 小売事業者としては報酬が 0 になるリスクが高く，互い に競争するよりも, 同じ電気料金に設定する方が安定的 に利益が得られることを学習したためである.

小売事業者数が 16 名以上になる Case (a)(5)(6)では, スイッチングコストが大きい Case (VI) を除いて競争が 激しくなり，電気料金が市場価格付近まで下がっている. 以上の結果は需要家種別が住宅である Case (a)の一例で あるが, 他の条件でのシミュレーションも同様の傾向を 示すことを確認している. 

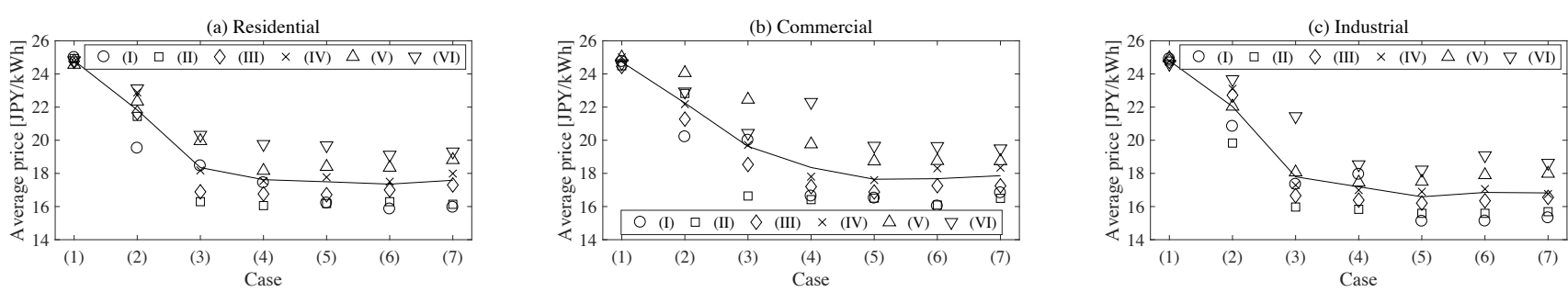

Fig. 9 Average of the selling price from 49,521 to 50,000 periods; Left: Case (a), Middle: Case (b), Right: Case (c)
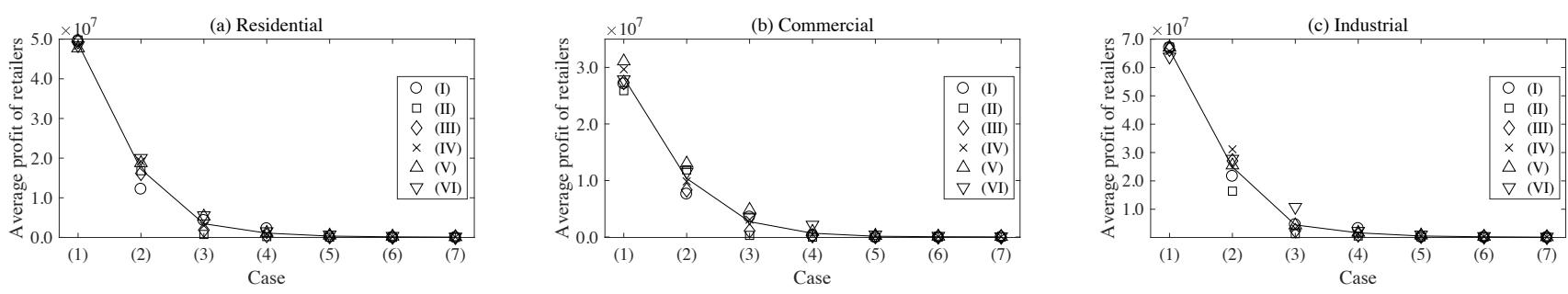

Fig. 10 Average profit of retailers from 49,521 to 50,000 periods; Left: Case (a), Middle: Case (b), Right: Case (c)

\subsection{2 考察}

電気料金の一か月平均值を，学習最後の 480 か月 （49,521 期 〜 50,000 期）に対して平均した值を Fig. 9 に, この期間において小売事業者エージェントが得た利益の 平均值を Fig. 10 に示す. Fig. 9 と Fig. 10 の横軸は Case $(1),(2), \ldots,(6)$ を, 凡例は Case (I), (II), ..., (VI) を示 す。また, 図中の直線は Case (I), (II), .., (VI)の值の 平均值を結んだものである。

\section{(1) 小売事業者数の影響}

7.4.1にて述べたように，小売事業者数が増加するに つれて電気料金の平均值は低下しており，それに伴い小 売事業者エージェントが獲得する利益も減少している. Case (5), (6), (7) は電気料金の分布がほぼ横並びになっ ているが, これはFig.9からもわかるように, Case (5),

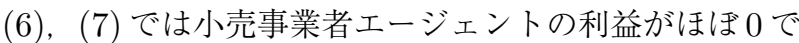
あり，これ以上電気料金を下げることができないためで ある。したがって, Case (5), (6), (7) では競争が激し く小売事業者エージェントが安定的な利益を得ることが できず，非現実的な状況となっていることから，これ以 降はCase (2)，(3)，(4)のみに焦点を絞って考察を行う.

(2) スイッチングコストの影響

スイッチングコストが大きいほど電気料金が高くなる 傾向があるのはFig. 9 からも見てとれる。ただし, 7.4.1 にて述べたように，スイッチングコストが 0 になる Case (I) では電気料金が上昇する場合があるため, Fig. 9 では Case (I) の電気料金が最小になっていない場合がある。

(3) ロードカーブの影響

ロードカーブが異なると，電気料金は若干ではあるが 異なる. Case (b)の電気料金は, Case (a)(c)の電気料 金よりも大きい.これは, Case (b)では市場価格が高騰 する昼間に商業需要家の需要が大きくなる傾向があるた めであり，高価な市場価格での電力調達費用を賄うため に，電気料金を高く設定していると解釈できる.
（4）小売事業者間の競争について

Fig. 11 は，学習最後の 480 か月（49,521 期 50,000 期）において小売事業者エージェントが獲得した利益の 分布を，エージェントごとに示したものである。横軸は 小売事業者エージェントの番号, 縦軸は利益であり, 需 要が無次元であることから利益も無次元にて表記してい る。グラフは箱ひげ図であり，外れ值を+印で表してい る.グラフの上には Case に対応する番号を示している. これも紙面の都合により，需要家が住宅の Case (a)のみ について表示する.

Case (a)(2)(I) より，2 名の小売事業者エージェント は等しい分布で利益を獲得しており, 契約している需要 家をほぼ等分する関係にある。これは，両者が等しい電 気料金を設定しており，かつ需要家のスイッチングコス トが0であるためである。Case (a)(2)(IV)(VI)でも同 様の結果が見られるが, Case (a)(2)(II)では両者の利益 に明確な差が存在する。これは，Fig. 12 に示したCase (a) (2) (II) の電気料金からもわかるように, 小売事業者 エージェント 1 よりも小売事業者エージェント 2 がわず かに電気料金を低く設定しているためである。この状態 で電気料金は安定しており，小売事業者エージェント 1 と 2 は積極的に競争をしていない.

Case (a)(2)(IV) における電気料金を Fig. 12 に示す. 小売事業者エージェント 2 が電気料金の上げ下げを繰り 返すことで，Fig. 11 では若干小売事業者エージェント 2 の利益が大きい。これは, Case (a)(2)(IV)ではスイッ チングコストが大きく, 電気料金を上昇させても小売事 業者エージェント 2 の利益が大きく低下しないためであ る。ただし，電気料金を上昇させたままだと小売事業者 エージェント 1 が電気料金を下げる行動をとり，競争に より両者の利益が低下するため，協調状態が崩れること を防ぐために電気料金の上げ下げを繰り返している.

Case (a)(3)(I)(II)(IV) では小売事業者数が多いため, 

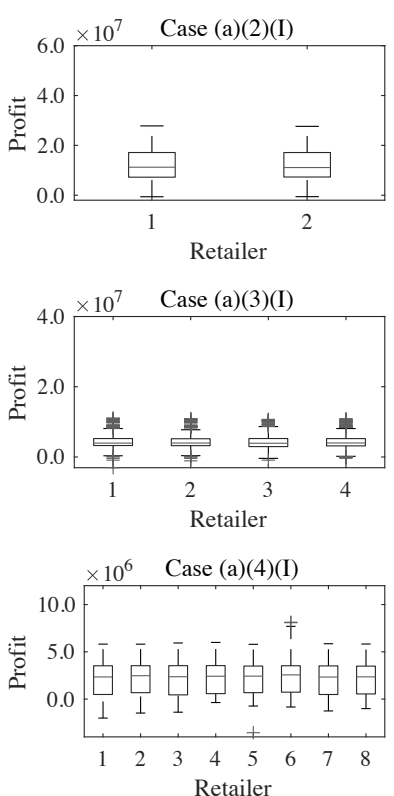
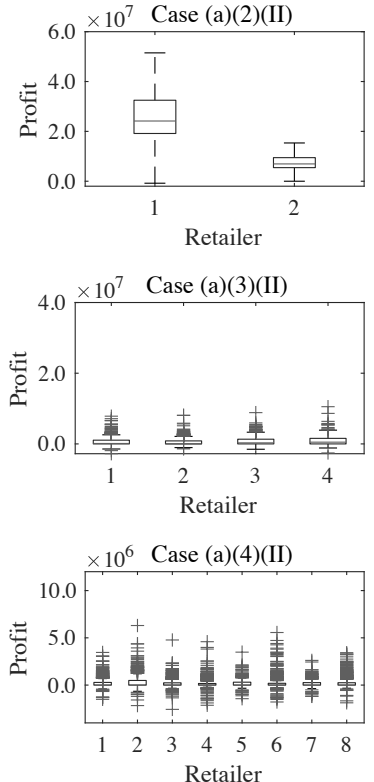
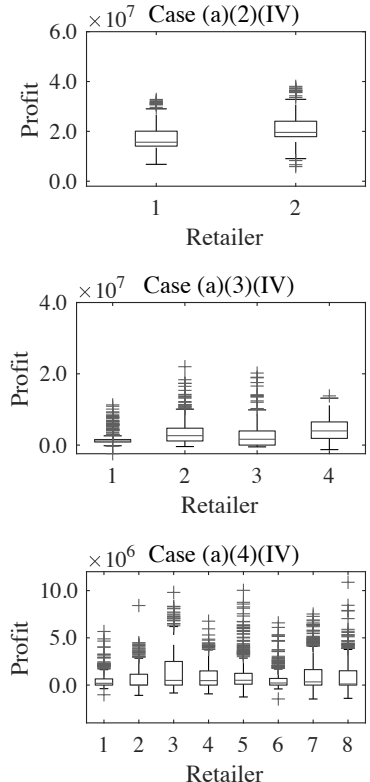
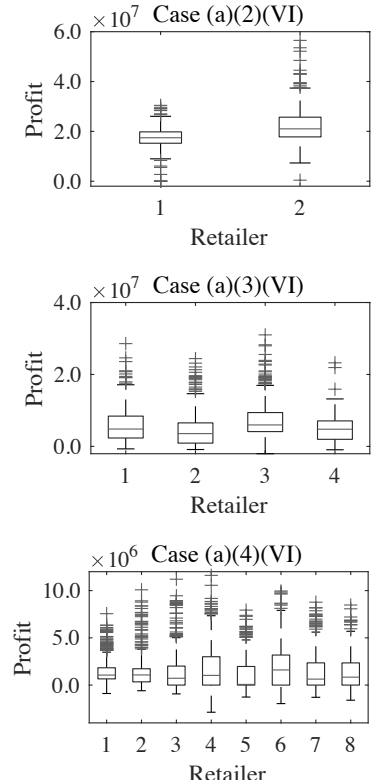

Fig. 11 Profit distribution of retailers from 49,521 to 50,000 periods in Case (a)
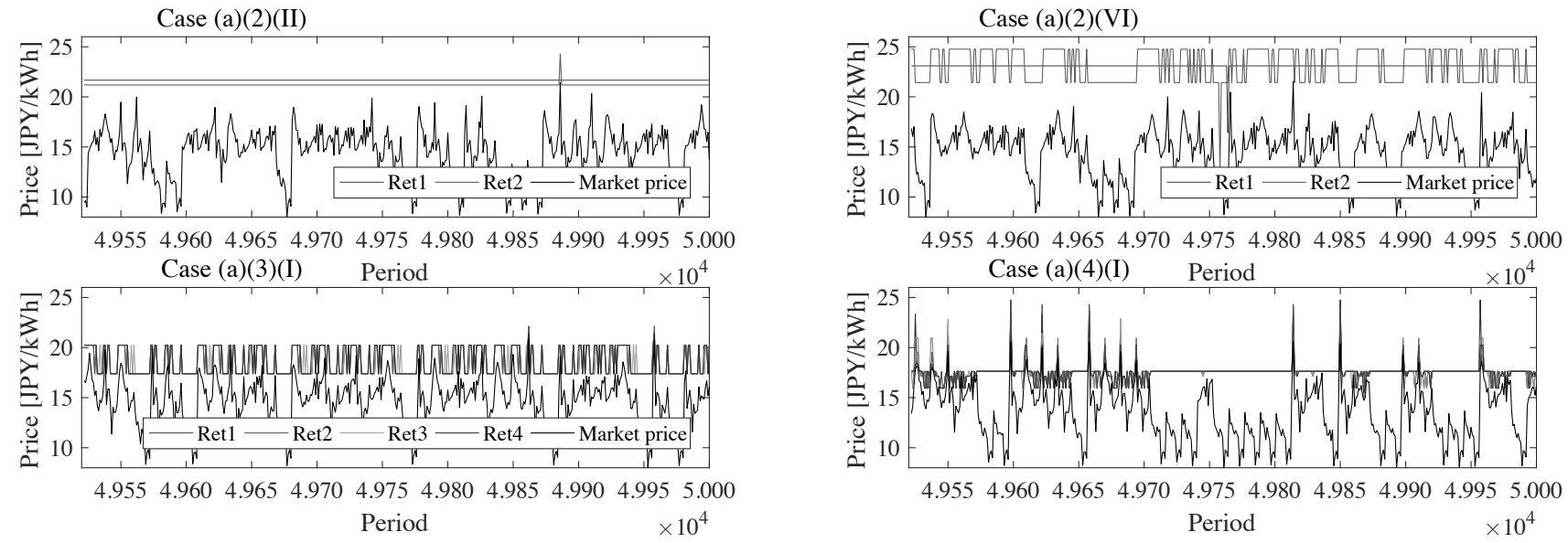

Fig. 12 The selling price from 49,521 to 50,000 periods in Case (a)

Case(a)(2) と比較して利益が小さい. Case (a)(VI)では スイッチングコストが大きいため, Case (a)(3)(I)(II)(IV) と比較して利益が大きい. Case (a)(3)(I) では競争が激 しくなってはいるが, 利益の分布に大きな偏りはない. これは, Fig. 12 に示したCase (a)(3)(I)の電気料金から わかるように，小売事業者エージェント $1,2,3,4$ が電 気料金をほぼ等しい值に設定しているためである，この 理由については前述の通り，スイッチングコストが 00 場合には，協調的に電気料金を設定した方が安定的に利 益が得られることを学習したためである.

Case (4)(I)(II)(IV)(VI) ではさらに小売事業者エー ジェントが増加し, 競争が激しくなっているため, 利益 がさらに小さくなっている，ただし，このような場合で も，スイッチングコストが0である Case (a)(4)(I)では, 利益に大きな偏りがない.これも，Fig. 12 に示したCase $(\mathrm{a})(4)(\mathrm{I})$ の電気料金からわかるように, 小売事業者エー ジェントが等しい価格で電気料金を決定しているためで
ある.さらに, Fig. 12 では市場価格が高騰する際に小売 事業者エージェントが一斉に電気料金を高く設定してお り，協調的に電気料金を上昇させることで利益の増加を 図っていることが確認できる。

以上の結果より, 小売事業者の競争が活発化すること で電気料金が下がり，スイッチングコストが低下すると その傾向が顕著になると解釈することができる，そのた め, 小売事業者間の競争を促進させるとともに, 需要家 がより安価な小売事業者と柔軟に契約可能な環境を整備 することが重要になると考えられる。一方で，いくつか の条件において, 小売事業者エージェントによる協調的 な電気料金の值上げあるいは競争回避行動が確認され た．小売事業者が利益を得ることを目的とする場合，競 争相手よりも電気料金を下げる行動が合理的であるが, シミュレーションでは, エージェントが過去の経験に基 づき適応的に行動することで，合理的とはいえない，つ まり電気料金を上昇させる行動をとり，その結果として 
利益が増加することを学習している．この結果は，小売 事業者の協調行動を誘発する要因が小売事業者の適応的 行動にあることを示唆している. Fig. 12 に示したCase $(\mathrm{a})(4)(\mathrm{I})$ の電気料金のように，市場価格の高騰時に大幅 に電気料金を上昇させて利益を増加させるような行為は, 適応的行動によって誘発されるため, こういった不適切 な行為を監視し，健全な競争を実現することが重要であ ると考えられる。

\section{8. おわりに}

本論文では，競争環境下における小売事業者の適応的 行動を分析することを目的として，複数の小売事業者 エージェントと需要家間の取引を模擬するエージェント ベースシミュレーションをクラシファイアシステムを用 いて実施した。 シミュレーション結果より，競争活発化 やスイッチングコストの重要性を再確認するとともに, 市場価格高騰時など特定の状況における電気料金の不当 な上昇やエージェントによる競争回避行動などの現象の 一要因が小売事業者の適応的行動であるという知見が得 られた。本論文は需要家を顧客とする競争環境下におけ る小売事業者の適応的行動分析に主眼を置き，限定的な 分析を行っているため, 分析範囲を拡張してより一般化 した知見を導く必要がある。また，数理モデルによって 記述した小売事業者間の均衡解と今回得られた結果を比 較し，適応的行動と合理的行動の差異についても検討す る必要がある。本論文で構築したシミュレーションシス テムを拡張し，より現実に即したシステムの開発を含め， これを今後の課題としたい

なお, 本研究の一部は JSPS 科研費 JP26820096, JP26282086 の助成を受けたものである.

\section{参考文献}

[1] 服部: 電力の小売全面自由化の実効性に関する検討-; メータリングシステムと需要家のスイッチングコストに 伴う問題を中心として-; 電力中央研究所報告, 研究報 告：Y06007 (Apr. 2007)

[2] 筒井, 佐藤, 後藤, 三枝, 服部: 欧州の電力小売全面自 由化と競争の実態-規制料金の現状・需要家の選択行動 · 供給者の対応-; 電力中央研究所報告, 研究報告：Y12017 (May. 2013)

[3] T. Krause, E. V. Beck, R. Cherkaoui, A. Germond, G. Andersson and D. Ernst: A comparison of Nash equilibria analysis and agent-based modeling for power markets; Electrical Power and Energy Systems, Vol. 28, pp. 599-607 (2006)

[4] D. Pozo and J. Contreras: Finding multiple nash equilibria in pool-based markets: A stochastic EPEC approach; IEEE Trans. Power Syst., Vol. 26, No. 3, pp. 1744-1752 (2011)

[5] P. Zou, Q. Chen, Q. Xia, G. He, C. Kang and A. J. Conejo: Pool equilibria including strategic storage; Applied Energy, Vol. 177, pp. 260-270 (2016)
[6] A. J. Conejo, M. Carrión and J. M. Morales: Decision Making Under Uncertainty in Electricity Market, Springer (2010)

[7] M. Carrión, J. M. Arroyo and A. J. Conejo: A bilevel stochastic programming approach for retailer futures market trading; IEEE Trans. Power Syst., Vol. 24, No. 3, pp. 1446-1456 (2009)

[8] M. Carríon, A. J. Conejo and J. M. Arroyo: Forward contracting and selling price determination for a retailer; IEEE Trans. Power Syst., Vol. 22, No. 4, pp. 2105-2114 (2007)

[9] R. García-Bertrand: Sale prices setting tool for retailers; IEEE Trans. Smart Grid, Vol. 4, No. 4, pp. 2028-2035 (2013)

[10] M. Zugno, J. M. Morales, P. Pinson and H. Madsen: A bilevel model for electricity retailers' participation in a demand response market environment; Energy Economics, Vol. 36, pp. 182-197 (2013)

[11] A. A. S. Algarni and K. Bhattacharya: A generic operations framework for DisCos in retail electricity markets; IEEE Trans. Power Syst., Vol. 24, No. 1, pp. 356-367 (2009)

[12] A. Safdarian, M. Fotuhi-Firuzabad and M. Lehtonen: A stochastic framework for short-term operation of a distribution company; IEEE Trans. Power Syst., Vol. 28, No. 4, pp. 4712-4721 (2013)

[13] A. Safdarian, M. Fotuhi-Firuzabad and M. Lehtonen: A medium-term decision model for DisCos: Forward contracting and TOU pricing; IEEE Trans. Power Syst., Vol. 30, No. 3, pp. 1143-1154 (2015)

[14] A. Safdarian, M. Fotuhi-Firuzabad and M. Lehtonen: Impacts of time-varying electricity rates on forward contract scheduling of DisCos; IEEE Trans. Power Deliv., Vol. 29, No. 2, pp. 733-741 (2014)

[15] R. Palma-Behnke, J. L. C. Arias, L. S. Vargas and A. Jofré: A distribution company energy acquisition market model with integration of distributed generation and load curtailment options; IEEE Trans. Power Syst., Vol. 20, No. 4, pp. 1718-1727 (2005)

[16] H. Haghighat and S. W. Kennedy : A bilevel approach to operational decision making of a distribution company in competitive environments; IEEE Trans. Power Syst., Vol. 27, No. 4, pp. 1797-1807 (2012)

[17] A. Hatami, H. Seifi and M. K. Sheikh-El-Eslami: A stochastic-based decision-making framework for an electricity retailer: Time-of-use pricing and electricity portfolio optimization; IEEE Trans. Power Syst., Vol. 26, No. 4, pp. 1808-1816 (2011)

[18] Q. Zhang and X. Wang: Hedge contract characterization and risk-constrained electricity procurement; IEEE Trans. Power Syst., Vol. 24, No. 3, pp. 15471558 (2009)

[19] S. A. Gabriel, A. J. Conejo, M. A. Plazas and S. Balakrishnan: Optimal price and quantity determina- 
tion for retail electric power contracts; IEEE Trans.

Power Syst., Vol. 21, No. 1, pp. 180-187 (2006)

[20] J. Kettunen, A. Salo and D. W. Bunn: Optimization of electricity retailer's contract portfolio subject to risk preferences; IEEE Trans. Power Syst., Vol. 25, No. 1, pp. 117-128 (2010)

[21] A. Ahmadi, M. Charwand and J. Aghaei: Riskconstrained optimal strategy for retailer forward contract portfolio; Electrical Power and Energy Systems, Vol. 53, pp. 704-713 (2013)

[22] J. M. Morales, S. Pineda, A. J. Conejo and M. Carrión: Scenario reduction for futures market trading in electricity markets; IEEE Trans. Power Syst., Vol. 24, No. 2, pp. 878-888 (2009)

[23] W. Wei, F. Liu and S. Mei: Energy pricing and dispatch for smart grid retailers under demand response and market price uncertainty; IEEE Trans. Smart Grid, Vol. 6, No. 3, pp. 1364-1374 (2015)

[24] M. H. Rothkopf: Daily repetition: A neglected factor in the analysis of electricity auctions; The Electricity Journal, Elsevier (1999)

[25] A. Weidlich: Engineering interrelated electricity markets; An Agent-Based Computational Approach, Physica-Verlag, A Springer Company (2008)

[26] G. Abrate, E. Bompard, R. Napoli and B. Wan: Multi-agent models for consumer choice and retailer strategies in the competitive electricity market; Working Paper 12, HERMES Research Center (2006)

[27] S. Yousefi, M. P. Moghaddam and V. J. Majd: Optimal real time pricing in an agent-based retail market using a comprehensive demand response model; Energy, Vol. 36, pp. 5716-5727 (2011)

[28] 菅野, 北, 田中, 長谷川: 電力系統における RPS 制度 の強化学習に基づく市場解析; 電学論 B, 126 巻, 2 号, pp. 217-224 (Feb. 2007)

[29] A. C. Tellidou and A. G. Bakirtzis: Agent-based analysis of capacity withholding and tacit collusion in electricity markets; IEEE Trans. Power Syst., Vol. 22, No. 4, pp. 1735-1742 (2007)

[30] N. P. Yu, C. C. Liu and J. Price: Evaluation of market rules using a multi-agent system method; IEEE Trans. Power Syst., Vol. 25, No. 1, pp. 470-479 (2010)

[31] 下村, 最所, 藤井, 山地: マルチエージェントモデルを 用いた電力市場における価格形成過程の分析; 電学論 B, 124 巻, 2 号, pp. 281-290 (Feb. 2004)

[32] Z. Zhou, F. Zhao and J. Wang: Agent-based electricity market simulation with demand response from commercial buildings; IEEE Trans. Smart Grid, Vol. 2, No. 4, pp. 580-588 (2011)

[33] P. R. Thimmapuram and J. Kim: Consumers' price elasticity of demand modeling with economic effects on electricity markets using an agent-based model; IEEE Trans. Smart Grid, Vol. 4, No. 1, pp. 390-397 (2013)
[34] A. J. Bagnall and G. D. Smith: A multiagent model of the UK market in electricity generation; IEEE Trans. Evol. Comp., Vol. 9, No. 5, pp. 522-536 (Oct. 2005)

[35] S. W. Wilson: Classifier fitness based on accuracy; Evolutionary Computation, Vol. 3, No. 2, pp. 149175 (1995)

[36] 井上, 玉, 下原: 行動価値に着目した学習分類子システ ムの改善 : マルチエージェント強化学習への接近; 情報 処理学会論文誌, Vol. 47, No. 5, pp. 1483-1492 (2006)

[37] R. Herranz, A. Muñoz San Roque, J. Villar and F. A. Campos: Optimal demand-side bidding strategies in electricity spot markets; IEEE Trans. Power Syst., Vol. 27, No. 3, pp. 1204-1213 (2012)

[38] S. E. Fleten and E. Pettersen: Constructing bidding curves for a price-taking retailer in the norwegian electricity market; IEEE Trans. Power Syst., Vol. 20, No. 2, pp. 701-708 (2005)

[39] S. J. Kazempour, A. J. Conejo and C. Ruiz: Strategic Bidding for a Large Consumer; IEEE Trans. Power Syst., Vol. 30, No. 2, pp. 848-856 (2015)

[40] 日本卸電力取引所 HP, http://www.jepx.org/

[41] 一般社団法人 電気学会 電力・エネルギー部門 HP, 電力系統の標準モデル, 第 II 部地域供給系 統モデル, http://www2.iee.or.jp/〜 pes/model/chiiki /index.html，(2016 年 1 月 5 日アクセス)

[42] 東京電力株式会社 HP, でんき予報, http:// www.tepco.co.jp/forecast/index-j.html，（2016年1月 5 日アクセス)

付 録

\section{需要生成手法}

季節，平日，休日を考慮した，毎日変動する住宅，商 業, 工業需要家のロードカーブを作成するために, 電気 学会地域供給系統の「系統 III $66 \mathrm{kV}$ 架空線地中線混在 系統 (架地混系統)」[41] の住宅, 商業, 工業需要家の需 要データと, 東京電力管内の需要実績データ [42] を用い る. 電気学会地域供給系統には毎日の需要のデータは存 在しないが, 需要実績データを用いてこれを補完する. 補完の方法としては, 需要実績データの一日のピーク需 要に比例した形で電気学会地域供給系統の需要デー夕を 増減させるというものである. 以下にその具体的な方法 を示す。

需要実績データに対応する日集合（2012 年 1 月 1 日か ら 2015 年 12 月 31 日までの 1,461 日）を $D_{y}$ とし， $d$ 日 における $t$ 期の需要実績を $P_{d, t}^{a c t}$ とする. 需要実績デー夕 の年集合を $Y$ とする. まず, $d$ 日における $t=1,2, \ldots, 48$ 期の需要 $P_{d, t}^{a c t}$ の 1 日の最大值（ピーク需要）を, 需要実 績データのすべての日 $d \in D_{y}$ について求める $(1,461$ 日 分). 求めた 1,461 日分のピーク需要 $P_{d}^{\max }$ は (A1) で計 算できる。 


$$
P_{d}^{\max }=\underset{t}{\arg \max } P_{d, t}^{a c t}, \quad \forall d \in D_{y}, \forall t \in T
$$

つぎに, $y \in Y$ 年の季節 $s \subset y \subset D_{y}$ における平日集合 $D_{w} \subset s$ に含まれる $d \in D_{w}$ 日および休日集合 $D_{h}$ に含ま れる $d \in D_{h}$ 日の中で, 最も $P_{d}^{\max }$ が大きくなる季節ピー ク負荷 $P_{y, s, w}^{\max }, P_{y, s, h}^{\max }$ を求める.つまり, $y$ 年の各季節に おいて需要の実績值が最も大きくなる日を，平日と休日 に分けて求める. $P_{y, s, w}^{\max }, P_{y, s, h}^{\max }$ は(A2),(A3) で求まる.

$$
\begin{array}{ll}
P_{y, s, w}^{\max }=\arg \max \left(P_{d}^{\max }\right), & d \in D_{w} \subset s \subset y \\
P_{y, s, h}^{\max }=\arg \max \left(P_{d}^{\max }\right), & d \in D_{h} \subset s \subset y
\end{array}
$$

求めた $P_{y, s, w}^{\max }, P_{y, s, h}^{\max }$ を基準として, $y$ 年の季節 $s$ にお ける $d \in s \subset y$ 日のピーク需要の季節ピーク負荷 $P_{y, s, w}^{\max }$, $P_{y, s, h}^{\max }$ に対する割合（平日，休日別） $\gamma_{y, d, w}, \gamma_{y, d, h}$ を (A4),(A5)により求める.

$$
\begin{array}{ll}
\gamma_{y, d, w}=\frac{P_{d}^{\max }}{P_{s, w}^{\max }}, & d \in D_{w} \subset s \subset y \\
\gamma_{y, d, h}=\frac{P_{d}^{\max }}{P_{s, h}^{\max }}, & d \in D_{h} \subset s \subset y
\end{array}
$$

割合 $\gamma_{y, d, w}, \gamma_{y, d, h}$ が求まったので, 地域供給系統需要 データの季節，平日，休日別の住宅，商業，工業需要家 の需要データ $P_{j, s, d, t}($ 需要家 $j$ の季節 $s$ における $d$ 日 $t$ 期 の需要) を用いて住宅, 商業, 工業需要家 $j$ の $d$ 日の $t$ 期 における需要 $P_{j, d, t}$ を(A6) で求める.

$$
\begin{aligned}
& P_{j, d, t}= \begin{cases}\gamma_{y, d, w} P_{j, s, d, t}, & \text { if } d \in D_{w} \subset s \subset y, \\
\gamma_{y, d, h} P_{j, s, d, t}, & \text { if } d \in D_{h} \subset s \subset y,\end{cases} \\
& \forall j \in L, \forall t \in T
\end{aligned}
$$

このとき, $P_{j, d, t}$ は 1 日を 24 分割した值であるため, 線 形補完で 30 分ごと 48 期分のデータに変換する. 以上の 手順を踏むことで，年，季節，平日，休日を考慮した， 1 日を 48 期に分割した 1,461 日分の，住宅，商業，工業需 要家の需要データが作成できる，本来であれば市場価格 と需要の相関を考慮することが望ましいが, JEPXのス ポット市場での取引量は現状では小さいため, 本論文で は需要と市場価格の相関が小さいものとして無視してい る。今後スポット市場での取引量が増加し, 需要との相 関が大きくなった場合には，より適切な需要デー夕の作 成手法が必要になると考えられる。これについては今後 の課題とする.

\section{市場価格および需要シナリオ生成手法}

前日市場価格データから前日市場価格シナリオを生 成する手法を述べる，需要シナリオも同様の手法で生成 可能である。 $d$ 日の $t$ 期における前日市場価格デー夕を $\lambda_{d, t}^{D A *}$ とし，これを基に分散共分散行列 $\boldsymbol{\Sigma}$ を計算する. $\lambda_{\boldsymbol{t}}^{\boldsymbol{D} \boldsymbol{A} *}=\left(\lambda_{1, t}^{D A *}, \lambda_{2, t}^{D A *}, \ldots, \lambda_{|D|, t}^{D A *}\right)^{T}$ を市場価格ベクトル
とする．Tは転置を表す，前日市場価格の時系列デー 夕セット行列を $\Lambda^{D A *}=\left(\lambda_{1}^{D A *}, \lambda_{2}^{D A *}, \cdots, \lambda_{48}^{D A *}\right)$ とす る. 分散共分散行列 $\boldsymbol{\Sigma}$ は

$$
\left[\begin{array}{ccc}
\boldsymbol{\Sigma}= & & \\
\operatorname{var}\left(\boldsymbol{\lambda}_{\mathbf{1}}^{D A *}\right) & \cdots & \operatorname{cov}\left(\boldsymbol{\lambda}_{\mathbf{1}}^{\boldsymbol{D A} *}, \boldsymbol{\lambda}_{\mathbf{4 8}}^{\boldsymbol{D A} *}\right) \\
\vdots & \ddots & \vdots \\
\operatorname{cov}\left(\boldsymbol{\lambda}_{\mathbf{4 8}}^{D A *}, \boldsymbol{\lambda}_{1}^{D A *}\right) & \cdots & \operatorname{var}\left(\boldsymbol{\lambda}_{\mathbf{4 8}}^{\boldsymbol{D A} \boldsymbol{A})}\right.
\end{array}\right]
$$

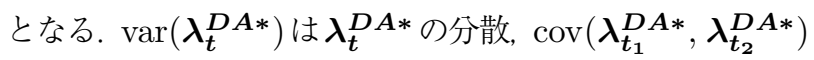
は $\boldsymbol{\lambda}_{\boldsymbol{t}_{1}}^{\boldsymbol{D A}}$ および $\boldsymbol{\lambda}_{\boldsymbol{t}_{2}}^{\boldsymbol{D A}}, t_{1}, \neq t_{2}$ の共分散である. $\boldsymbol{\Sigma}=$ $Q Q^{T}$ を満たす $Q$ を特異值分解を用いて求め, $\boldsymbol{X}$ を一 様乱数ベクトルとする. シナリオ集合を $\Omega$, シナリオを

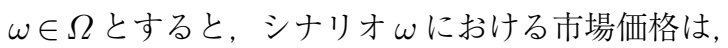

$$
\boldsymbol{\lambda}_{\boldsymbol{\omega}}^{\boldsymbol{D} \boldsymbol{A}}=\boldsymbol{Q} \boldsymbol{X}+E\left(\boldsymbol{\Lambda}^{\boldsymbol{D A} *}\right), \quad \forall \omega \in \Omega
$$

と計算できる。 $E\left(\Lambda^{D A *}\right)$ はデータセット $\Lambda^{D A *}$ に対応 する期間における前日市場価格の平均值である.

\section{著者略歴}

\section{関荎喜真也 (正会員)}

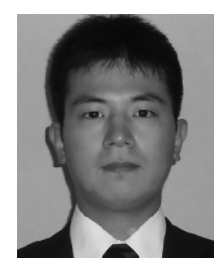

1986 年 5 月 9 日生. 2013 年 9 月名古屋 工業大学大学院工学研究科創成シミュレー ション工学専攻博士後期課程修了. 同年 10 月より広島大学大学院工学研究院電気電子 システム数理部門特任助教を経て，2016 年同大学助教となり, 現在に至る。主とし て電力市場における経済主体の意思決定, 送配電系統におけ る電力品質管理に関する研究に従事. 博士 (工学).

皆剀奇的郎 (正会員)

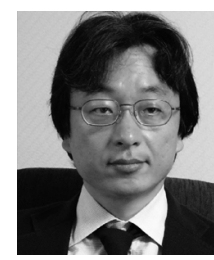

1959 年生. 1982 年神戸大学工学部卒業, 1984 年同大学院工学研究科修士課程修了. 同年新日本製鐵株式会社入社, 1990 年京 都大学経済研究所助手, 1993 年摂南大学 経営情報学部助教授, 1997 年広島大学工 学部助教授を経て, 2002 年同大学大学院 工学研究科教授となり, 現在に至る。意思決定およびゲーム 理論に関する研究に従事. 博士 (工学).

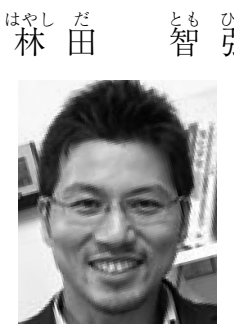

(正会員)

1980 年生. 2004 年広島大学工学部卒業, 2006 年同大学院工学研究科博士課程前期 修了. 同年広島大学大学院工学研究科助 手, 2007 年助教を経て, 2015 年准教授と なり，現在に至る．意思決定およびマルチ エージェントシステムに関する研究に従 事. 博士 (工学). 